\title{
WHITE-WINGED DOVE IN THOMPSON, MANITOBA
}

RUDOLF F. KOES, 135 Rossmere Crescent, Winnipeg, MB. R2K 0G1.

The White-winged Dove, a southern relative of the Mourning Dove, ranges from parts of South America through Central America into the southwestern United States. It is largely resident, although the northernmost breeders retreat south (and east?) for the winter. Given the species' propensity for long-distance wandering, with numerous sightings along the West Coast to Alaska and along the East Coast to the Maritimes and Newfoundland, it could be expected to turn up more frequently than it does in Canada and the central U.S. ${ }^{3}$ There are only two records for Minnesota (13 October 1985 at Duluth and 15 September 1994 at Hawk Ridge) and none for the Dakotas, Alberta and Saskatchewan. ${ }^{3,4,5}$ A bird captured and banded on 16 August 1995 at Thunder Cape Bird Observatory near Thunder Bay, Ontario was apparently the second for the area. ${ }^{2}$

On 13 August 1995, Zoe and Ray Irving noted a dove which had landed on a utility wire above their backyard in Thompson. The Irving home is situated in a well-wooded area near the outskirts of town, which in turn is located deep in the boreal forest in north-central Manitoba $\left(55^{\circ} 45^{\prime} \mathrm{N}, 97^{\circ} 51^{\prime} \mathrm{W}\right)$. As Mourning Doves are rare in the area, the Irvings' interest was piqued. After careful observation and reference to a field guide, the bird was identified as a White-winged Dove. Local birder Wally Jansen, compiler of the Thompson Christmas Bird Count, was notified. Although Mr. Jansen was skeptical, he arrived shortly and, after observing the bird as it fed in the backyard, concurred with the identification. He, in turn, notified Robert Parsons in Winnipeg and later that evening word spread through the southern Manitoba birding community.

The next day I phoned the Irvings who confirmed the bird's continued presence. I decided to drive up on the 15th. After reaching Thompson in mid-afternoon I was invited in and installed myself on the screened-in veranda with a good view of the backyard with all its feeders. During the long wait we watched the comings and goings of a flock of grackles and one Yellow-headed Blackbird, a local rarity. Wally Jansen and Ray Irving arrived later and several diagnostic photographs taken on the 13th by Mr. Irving were circulated. Any remaining doubts on my part were erased. But was the bird still around?

At about 5:20 p.m. the dove suddenly landed in the yard. It fed for several minutes on the ground, hopped onto a birdbath where it took a few sips and sat for a moment, and then flew into an aspen bluff behind the house. The bird was not seen again that day. In size and shape it was similar to a Mourning Dove. The identifying features were its greyer 


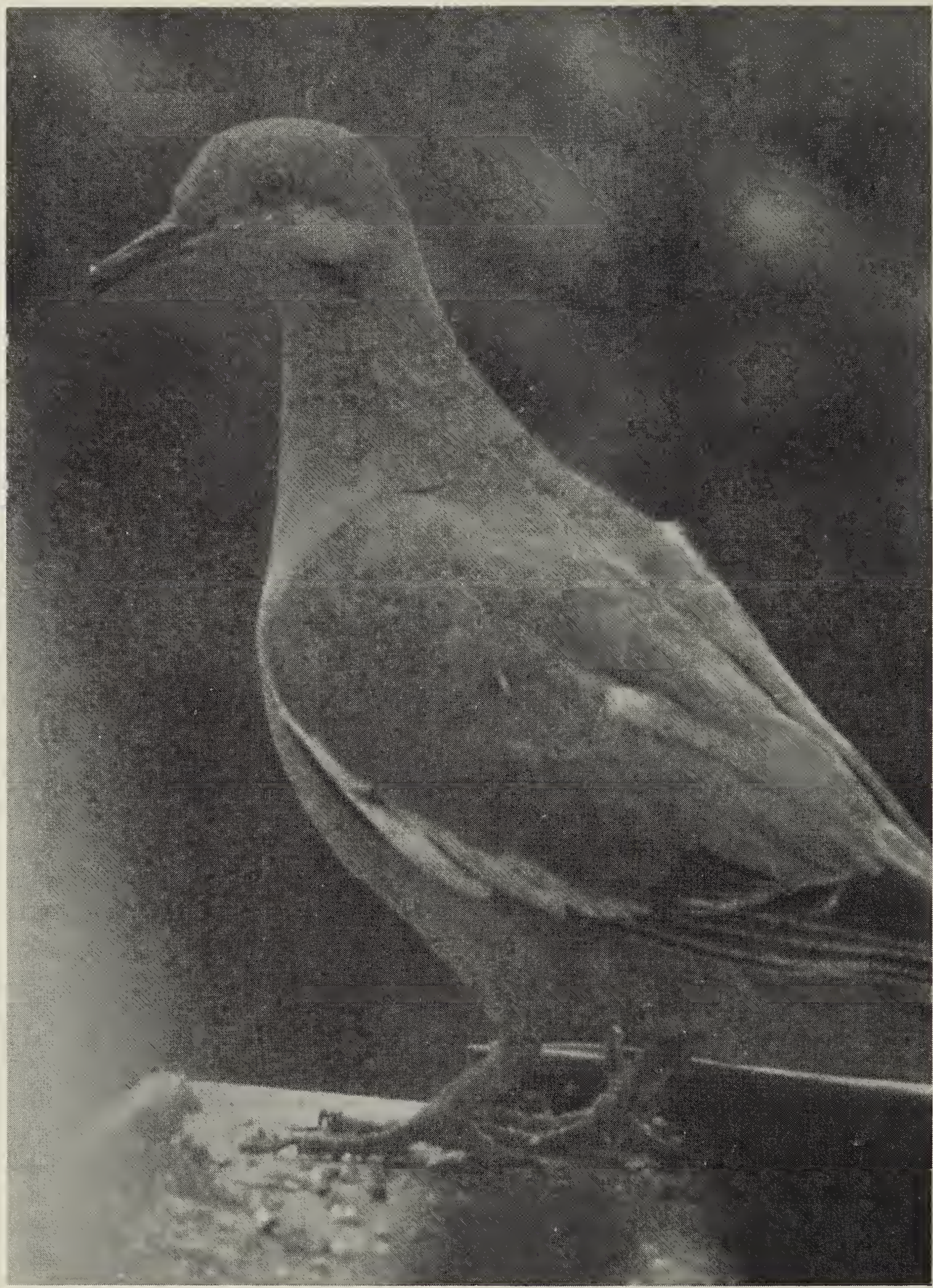

White-winged Dove, Thompson, Manitoba, early September 1995

Ray Irving

plumage, the bold white slash on its wings, the rounded tail with whitetipped outer retrices, a distinct black mark on the lower ear patch, and an area of bluish skin around the eye. The bird showed no sign of having been in captivity.

Over the next few weeks the
White-winged Dove visited the yard daily, frequently in the company of a small flock of grackles and the aforementioned Yellow-headed Blackbird. With fall approaching, and the dove showing no sign of wanting to depart on its own, Mrs. Irving became concerned about its future. Surviving a winter in Thompson would clearly be 
out of the question. Wally Jansen constructed a trap and the bird was finally caught on 5 September. The capture was described to me in a most entertaining letter by Mrs. Irving, part of which follows: "Two days later on Tuesday morning Delores, after much deliberation, sashayed her way into the trap. Faced with the moment of truth I folded! My heart beat faster than a chickadee's wing, my middle-aged body broke out in a hot flush and I sank onto the couch calling to Ray, 'Do it quickly, do it quickly.' He was, at the time, engaged in the manly task of tidying his tools, so he had not seen Delores's actions. However, my statement did arouse his interest and he turned to me with a glint in his eye, a readiness to comply and asked 'Do what, my dear?' It was a moment frozen in time. The bird standing centrally under the trap. The trap poised to fall, the string lying inert in my trembling hand. 'Pull the damned string' I croaked in desperation. Being a nimble-minded fellow, Ray changed his orientation in a flash, grabbed the string and pulled. Down came the trap."

Through the kindness of Calm Air, "Delores," as the dove was now called, was transported to Winnipeg on 7 September. The navigator of the flight, on whose lap Delores was travelling in a box, reported that the bird had difficulty reading his map as she only spoke (and read) Spanish. After arrival at the Manitoba Wildlife Rehabilitation Organization facility in Glenlea near Winnipeg, the dove was found to be infected with roundworms - a common affliction - but otherwise in good health. The notion of sending the bird back to the United States, where it had no doubt originated, had to be abandoned due to export permit problems. In November the dove was placed in the Winnipeg Zoo where it will hopefully enjoy a long and healthy stay.

What brought a White-winged Dove to Thompson remains a mystery. Although there had been a hot and extremely windy period in southern Manitoba a few days before the dove was discovered in Thompson, it seems unlikely that such a strong flier would be blown so far off course. It was more likely a case of reverse migration. The bird had found Thompson, and the Irving's wellstocked backyard, a safe haven, when it accidentally wandered into the vast boreal forest of Manitoba.

Acknowledgements I would like to thank Zoe and Ray Irving for their hospitality during my stay in Thompson and for their concern for the well-being of the dove. Thanks are also due to Wally Jansen for informing the Manitoba Rare Bird Alert and for building the trap, and to Robert Nero and Peter Taylor for their helpful comments on a draft of the manuscript.

1. AMERICAN ORNITHOLOGISTS' UNION. 1983. Check-list of North America birds, 6th ed. Allen Press, Lawrence, KS. 877 pp.

2. BAIN, M. and M. HOLDER (eds.). 1995. Cross Canada round-up. Birders Journal 4:220.

3. DE SANTE, D. and P. PYLE. 1986. Distributional checklist of North American birds, vol. 1: United States and Canada. Artemesia Press, Lee Vining, CA. 422 pp.

4. JANSSEN, R.B. 1987. Birds in Minnesota. University of Minnesota Press, Minneapolis, MN. 352 pp.

5. NICOLETTI, F.J. 1995. Minnesota's second White-winged Dove. Loon 66:213-214. 